\title{
LUDWIK FEUERBACH A TRANSCENDENTALNA METODA W KRYTYCE RELIGII
}

\section{Feuerbachowska krytyka religii jako hermeneutyka religijnej świadomości}

Feuerbach był jednym z najbardziej wpływowych krytyków religii. Jednakże nie zadowalał się tym, aby być tylko jej krytykiem. Uważał samego siebie przede wszystkim za jej komentatora. W przedmowie do drugiego wydania swej książki $O$ istocie chrześcijaństwa ${ }^{1}$ pisał: „Ja [...] pozwalam religii samej się wypowiadać, jestem tylko jej słuchaczem, tłumaczem, nie zaś suflerem"2. Nie twierdził też, że religia — a zwłaszcza chrześcijaństwo — jest czymś mało ważnym. Chciał natomiast doprowadzić - jak sam uważał - do lepszego zrozumienia istoty religijnego posłannictwa. Pisał więc: „[...] ja wcale nie mówię [...]: Bóg jest niczym, Trójca jest niczym, słowo boże jest niczym itd.; wykazuję tylko, że nie są one tym, czym są w złudnym wyobrażeniu teologii"3.

Religia i chrześcijaństwo - tak jak on to widział - nie są więc po prostu czymś nieprawdziwym. Dopiero teologia — wskazywał - jakkolwiek jest ona refleksją wypływającą z samej religii, doprowadza człowieka do tego, iż błędnie rozumie on posiadane przez siebie religijne przedstawienia, symbole i pojęcia. Ilekroć człowiek mówi o Bogu, tylekroć — jak twierdzi Feuerbach — wypowiada się on w rzeczywistości o swojej własnej istocie i dopiero teologia doprowadza go do fałszywego mniemania, iż mówiąc o Bogu, wypowiada się o innej Istocie: innej niż jego własna istota.

W jaki sposób Feuerbach rozumiał oraz jak uzasadniał to swoje szczególne ujęcie religii? Otóż przede wszystkim uważał on, że najważniejszym zadaniem, jakie należy wykonać jeszcze przed wszelkim interpretowaniem religii, jest opis religijnej świadomości. Ta religijna świadomość wskazywał — nie jest

\footnotetext{
* Poniższy tekst jest poszerzoną wersją wykładu wygłoszonego w języku niemieckim przez autora podczas sympozjum Z problematyki wspótczesnej filozofii religii, 17 XI 1988, w Papieskiej Akademii Teologicznej w Krakowie. 1843.

${ }^{1}$ L. Fe u e rb a ch, Das Wesen des Christentums, 1 . Auflage, Leipzig 1841; 2. Auflage, Leipzig

${ }^{2}$ Tenże, O istocie chrześcijaństwa, tł. A. Langmann, Warszawa 1959, s. 23.

${ }^{3}$ Tamże, s. 26.
} 
po prostu świadomością dotyczącą tego, co nieskończone. Jest ona natomiast świadomością własnej skończoności człowieka, odkrywającego własne znajdowanie się w obliczu tego, co nieskończone. Odpowiednio też religia nie jest dla Feuerbacha po prostu miłością człowieka do tego, co nieskończone. Jest ona natomiast dla niego skończoną miłością, którą człowiek zawdzięcza temu, co nieskończone, tzn. temu, co jest miłujące w sposób nieskończony. Nie jest też ona - powiada - prostym poświęceniem się człowieka dla tego, co nieskończone, lecz należy ją rozumieć jako człowiecze współspełnienie oraz następcze spełnienie (als menschliche Mitvollzug und Nachvollzug) tego poświęcenia, jakim to, co Nieskończone ofiarowało siebie dla świata. Kto przeto chce naprawdę zrozumieć czym jest religia, ten musi wyjaśnić, w jaki to sposób człowiek dochodzi do tego, że uprzytamnia sobie siebie samego jako skończoną istotę, która konstytuuje się w relacji do tego, co nieskończone.

Z zadaniem tym wiąże się przejście od opisu religijnej świadomości do jej interpretacji. Ta Feuerbachowska interpretacja jest nam już znana. Zgodnie z nią — jak pamiętamy — religijna samoświadomość człowieka polega na tym, że rozumie on siebie samego jako istotę skończoną, która konstytuuje się poprzez relację do nieskończonej rzeczywistości. Tę nieskończoną rzeczywistość stanowi - jego zdaniem gatunek (rodzaj) ludzki. Tak więc skończoność ludzkiej istoty konstytuuje się jako wyraz stosunku, jaki istnieje pomiędzy ludzkim indywiduum a gatunkiem (rodzajem) ludzkim.

Z tego wszystkiego wypływa pytanie, jakie winien sobie postawić uważny czytelnik Feuerbacha. Pytanie to brzmi: W jakiż to sposób doszedł Feuerbach do ujęcia gatunku (rodzaju) ludzkiego jako tego, co nieskończone? Otóż, zmierzając ku odpowiedzi na to pytanie, należy najpierw dokładnie określić, z jakiego to punktu widzenia rozważał on ów gatunek (rodzaj) ludzki. Pokaże się wówczas, że jest to - choć często w sposób ukryty — punkt widzenia filozofii transcendentalnej. Staje się to wyraźne, gdy się ukaże, iż używając w ten sposób pojęcia gatunku, zmierzał on do rozjaśnienia swoistości świadomości religijnej. Należy w tym celu wspomnieć również o innym jeszcze pojęciu, jakiego Feuerbach używał w związku z tamtym pojęciem gatunku. Idzie tutaj mianowicie o pojęcie „koniecznego przedmiotu”.

\section{Przedmiot wypowiedzi religijnej jako „przedmiot konieczny”}

Swoistość wypowiedzi religijnych wiąże się z ożywiającym je roszczeniem. Zgodnie $\mathrm{z}$ tym roszczeniem nie wypowiadają się one na jakiś dowolny temat, lecz odnoszą się do tego, co ,jedynie konieczne” (unum necessarium). Słuchacz powinien być zainteresowany tym ich szczególnym tematem nie z racji swoich subiektywnych skłonności lub potrzeb, lecz właśnie dlatego, iż jego 
własna świętość (bądź jej brak) zależy od jego stosunku do tego, o czym religijna wypowiedź mówi.

Wyłania się obecnie pytanie: jakie warunki musi spełniać przedmiot, ażeby mógł uzyskać rangę przedmiotu koniecznego? Otóż filozoficzna odpowiedź na to pytanie brzmi: Taki tylko przedmiot może mieć charakter koniecznego przedmiotu poznania, którego poznanie warunkuje możliwość wszelkich innych poznań. Zarazem też coraz jaśniejsze jego poznanie warunkuje wzrost jasności wszelkich innych poznań. Ludzie religijni skłonni są zgadzać się z tą filozoficzną odpowiedzią. Powiadają bowiem, że bez uprzedniego poznania Boga żaden inny przedmiot nie może zostać naprawdę poznany. Jest tak zaś dlatego, ponieważ Bóg jest światłem, dzięki któremu duch ludzki staje się w ogóle zdolny do poznania. Światło to zarazem czyni w ogóle widzialnymi wszelkie przedmioty, tj. czyni je poznawalnymi.

Stawiając dalej pytanie o to, czym byłby właściwie ów przedmiot, którego poznanie warunkowałoby możliwość wszelkiego innego poznania, uzyskuje się taką oto odpowiedź filozoficzną: Koniecznym warunkiem wszelkiego przedmiotowego poznania jest samopoznanie. O ile jednak poznanie przedmiotu, który jest różny od poznającego podmiotu, ma mieć charakter konieczny, musi się w tym celu dać najpierw wykazać, iż to, co inne, z którym poznające $j a$ nie jest identyczne, tak jest przyporządkowane ludzkiemu podmiotowi, iż człowiek uczy się pojmować siebie samego tylko dzięki temu, że już uprzednio zapoznał się z tym czymś innym, które jest dla niego koniecznym przedmiotem. Można by to również inaczej jeszcze wyrazić: koniecznym przedmiotem może być tylko to, co wychodzi jakby naprzeciw człowieka, jako jemu istotowo przyporządkowane a zarazem od niego różne. Dopiero też w spotkaniu z czymś takim znajduje czlowiek drogę do poznania siebie samego. Jednakże nie zostało jeszcze przez to powiedziane, w jaki to sposób należałoby rozumieć fakt, iż człowiek nie posiada żadnego bezpośredniego poznania samego siebie i dlatego potrzebuje już uprzedniego poznania tego, co inne. Jak więc należałoby opisać ten wstępny krok do zapośredniczonego samopoznania? A ponadto: Jak powinno być rozumiane „to, co inne względem człowieka”, które mu zapośrednicza owo samopoznanie? Dopiero gdyby się to wiedziało, mogłoby się zrozumieć, co właściwie myśli religijny człowiek, gdy mówi, że Bóg jest dla niego tym, co bardziej jest mu znane niż on sam sobie.

To są właśnie pytania, na które Feuerbach pragnie odpowiedzieć, gdy mówi: „Przedmiot (...), do którego podmiot odnosi się w sposób istotny i konieczny - to nic innego, jak tylko jego własna, ale uprzedmiotowiona istota" 4 . „Stąd też ilekroć uświadamiamy sobie jakiś przedmiot, uświadamiamy sobie zarazem naszą własną istotę"5. Tym samym zostało powiedziane, że to, co inne

${ }^{4}$ Tamże, s. 44.

5 Tamże, s. 46. 
— ta różna od człowieka rzeczywistość, którą on musi poznać, aby dzięki temu poznać samego siebie i aby zarazem stać się zdolnym do poznania czegokolwiek - stanowi ,istotę" (Wesen) człowieka. Ta jego własna istota jest właśnie jego koniecznym przedmiotem. Lecz również Bóg określany jest przez religijnego człowieka jako jedyny konieczny dla niego przedmiot. Wynika z tego - zdaniem Feuerbacha - następujący wniosek: to, co religijny człowiek mówi o Bogu jako o jedynym koniecznym przedmiocie, staje się wówczas filozoficznie zrozumiałe, gdy się przyjmie, że myślenie religijne stanowi tylko pewien obrazowy sposób, w jaki człowiek bezwiednie ujmuje swą własną istotę.

\section{Istota oraz gatunek - dwa centralne pojęcia Feuerbachowskiej filozofii transcendentalnej}

W dotychczasowych rozważaniach zostało już wskazane, że słowo gatunek oznacza u Feuerbacha tę nieskończoną rzeczywistość, do której człowiek musi się odnosić, aby uprzytomnić sobie swoją własną skończoność. Zaś słowo istota oznacza dlań tę - przyporządkowaną do człowieka — rzeczywistość, jaką on musi poznać, ażeby dzięki temu mógł poznać samego siebie i aby zarazem stał się przez to zdolny do poznawania jakichkolwiek zewnętrznych przedmiotów. W obydwu tych ważnych aspektach pojęcia gatunek oraz istota pokrywają się z pojęciem Boga. Czy to jednak oznacza — jak mniemal Feuerbach —że pojęcia te są równoznaczne z pojęciem Boga? Wszak gdy dwa lub trzy pojęcia pokrywają się ze sobą co do pewnych składników, nie wyklucza to przecież możliwości, że w innych, nawet znacznie ważniejszych składnikach, radykalnie od siebie się różnią. W jakiż przeto sposób dochodzi Feuerbach do przekonania, że religijne pojęcie Boga nie oznacza nic innego, jak tylko to samo co pojęcia gatunku oraz istoty? A ponadto: dlaczego uważał on, że te dwa pojęcia są znacznie jaśniejsze od religijnego pojęcia Boga?

Ażeby odpowiedzieć na powyższe pytania należy najpierw wyjaśnić, w jakim znaczeniu używa Feuerbach pojęć gatunku oraz istoty. Otóż, on sam daje nam tutaj ważną wskazówkę, gdy mówi: „... tylko istota, dla której przedmiotem jest jej własny rodzaj, jej własna istota, może inne rzeczy lub istoty uczynić dla siebie przedmiotem zgodnie $\mathrm{z}$ ich istotną naturą" 6 . Ta właśnie wypowiedź pozwala - przede wszystkim — poznać to pytanie, na które Feuerbach pragnie odpowiedzieć, wypowiadając się na temat istoty oraz gatunku. Pragnie on zrozumieć, na czym polega właściwa człowiekowi zdolność do tego, aby czynić przedmiotem (swego) poznania oraz chcenia innej osoby i rzeczy ,zgodnie $\mathrm{z}$ ich istotową naturą", a nie tylko w ich aspektach akcydentalnych. Otóż ten zamiar, aby poznawać rzeczy zgodnie $\mathrm{z}$ ich istotową naturą, implikuje

\footnotetext{
${ }^{6}$ Tamże, s. 40.
} 
„myśl o czymś w ogóle ode mnie innym, innym co do istoty"7, a zatem implikuje myślenie, iż rzeczy te są czymś więcej niż tylko tym, co się pokazuje obserwatorowi. Posiadają one bowiem swą własną istotę przejawiającą się w tym, że oto istnieją one samodzielnie naprzeciw obserwatora. Człowiek posiada zdolność odróżniania rzeczy (i osób) jako zjawisk dla oglądającego je podmiotu, oraz tego, czym one są zgodnie ze swoją istotną naturą. Uzdolnienie to -wskazywał Feuerbach - decydująco odróżnia człowieka od zwierząt. Na czym jednak polega ta specyficznie ludzka zdolność? Zacytowana wyżej wypowiedź Feuerbacha udziela nam właśnie odpowiedzi na to pytanie. Wszak rozróżnienie pomiędzy zjawiskiem rzeczy a jej ,istotą naturalną” umożliwione jest przez fakt, iż to, co poznawane, zwraca na siebie w podobny sposób uwagę innych podmiotów poznających. Podobne rzeczy bądź osoby pokazują się nie tylko jednemu podmiotowi, lecz i innym podmiotom. „Myśl o czymś w ogóle ode mnie innym, innym co do istoty, powstaje we mnie dopiero dzięki myśli o czymś innym, ze mną co do istoty tożsamym"8, a zatem poprzez myślenie innych podmiotów, które są poznającymi ludźmi tak jak ja. „Inny człowiek jest więzią łączącą mnie ze światem"9. Identyczność obiektu uświadamia mi się właśnie dzięki różnorodności poznających podmiotów. Dopiero też przez to zwracam uwagę na różnicę, jaka istnieje pomiędzy zmiennymi aspektami, ujawnianymi przez ten sam przedmiot różnym obserwatorom, a istotną naturą tegoż przedmiotu, która jest zasadniczo taka sama dla wszystkich obserwatorów.

Jednakże te rozróżnienia należy jeszcze doprecyzować. Albowiem również to, czym są rzeczy i osoby dla wielości ludzi, jest tylko ich zjawiskiem, które jest uwarunkowane wspólnymi właściwościami wielości obserwatorów. Nie stanowi to zatem jeszcze „istotnej natury” tychże rzeczy bądź osób. Raczej należy wątpić, czy tę ich „,istotną naturę” będziemy mogli kiedykolwiek poznać. Jednakże do tego, że stawiamy sobie taki cel (być może nieosiągalny), jest czymś nieodzownym poddanie naszego poznawania regule, która orzeka: Chcemy próbować tego, aby tak rzeczy rozważać, jak one ukazują się dla każdego człowieka, a nie tylko dla ograniczonej liczby obserwatorów. Albowiem (prawdziwie) powszechna ważność jest jedynym kryterium, uzasadniającym nam obiektywną ważność dokonywanych przez nas poznań. Z tego zaś wynika, że gdy ustanawiamy sobie jako cel, aby rzeczy i osoby poznawać pod względem ich istotnej natury, wówczas usiłujemy rozważać je w taki sposób, przy którym każde poszczególne ludzkie indywiduum może być zastąpione przez każde inne ludzkie indywiduum. Każde ludzkie indywiduum jest bowiem w stosunku do owego poznawczego usiłowania reprezentantem wszelkiego rozumnego podmiotu, ponieważ jest ono reprezentantem gatunku (rodzaju ludzkiego).

\footnotetext{
7 Tamże, s. 156.

8 Tamże, s. 156.

9 Tamże, s. 157.
} 
W tym właśnie znaczeniu pisał Feuerbach: „Przez to, że myślę, ja sam jestem [jakby] wszystkimi ludźmi” (cogitans... ipse ego sum omnes homines).

Wszystko to razem zdaje się nasuwać następującą interpretację: pojęcie gatunku, którego Feuerbach używa w książce $O$ istocie chrześcijaństwa, nie wyczerpuje się w określaniu sumy ludzkich indywiduów. Gdyby bowiem takie było dlań znaczenie owego pojęcia, wtedy byłoby czymś całkowicie niezrozumiałym to, dlaczego mówi on o gatunku jako o tym, co jest nieskończone. Choć bowiem wielka suma skończonych indywiduów od biedy może być określana jako „bez końca” (endlos), to przecież nigdy nie może ona być prawdziwie „nieskończona” (unendlich). Otóż zamiast tego, pojęcie gatunku oznacza pewną ideę regulatywną, tzn. pewne wyobrażenie celu. Wyobrażenie to dyktuje (czy też przepisuje) określoną regułę co do sposobu używania rozumu. Chodzi w niej o to, aby myśleć wyłącznie jako uniwersalnie zastępowalny reprezentant wszelkiego rozumnego podmiotu oraz aby zgodnie z tym sposobem myślenia postępować. To przedstawienie celu jest o tyle nieskończone, o ile dyktuje nam ono powinność porzucenia tych wszystkich przymiotów poznania i chcenia, które nie są uwarunkowane konkretną skończonością indywiduum. W takim to znaczeniu rozumiał Feuerbach każdy akt poznania jako „tryumf” rozumu nad tym, co indywidualne. Każdy zaś moralny czyn uważał za „tryumf” moralnego chcenia nad poszczególnym człowiekiem. Tak więc ludzkie indywiduum poddaje się — choćby bezwiednie - owemu przedstawieniu celu w każdym akcie poznania i w każdym moralnym czynie. Staje się ono przez to wówczas samym tylko (jakby) reprezentantem gatunku. Dlatego Feuerbach może również powiedzieć: Każdy taki akt — poznawczy i moralny — jest tryumfem gatunku nad indywiduum.

Lecz właśnie ten fakt, że możemy się poddać owemu wyobrażeniu celu, konstytuuje istotę człowieka jako istoty rozumnej. Wszak stanowi to jego istotę (essentia), że może on stawiać sobie zadania tego rodzaju, aby coś teoretycznie twierdzić lub praktycznie czegoś chcieć. Zadania te określają to, co może on twierdzić, oraz czego może on chcieć, w imieniu wszystkich ludzi, czyli w imieniu gatunku ludzkiego. Zarazem jednak jego doświadczeniem jako indywiduum staje się również to, iż nie może on tych zadań do końca wypełnić. Doświadcza on na przykład tego, jak bardzo w spełnianym przez siebie poznawaniu i chceniu jest ograniczony do ram (swych) indywidualnych perspektyw. Lecz właśnie tylko poprzez doświadczenie tychże ograniczeń uprzytamnia on sobie swą własną indywidualność. W tym właśnie znaczeniu gatunek (rozumiany jako idea regulatywna, służąca do tego, aby poddawszy się jej myśleć i postępować jako uniwersalnie zastępowalny reprezentant wszelkiego rozumnego podmiotu) jest tym, co nieskończone. Człowiek musi go poznać, aby w ogóle mógł sobie uprzytomnić swoją własną skończoność jako indywiduum. Ponieważ zdolność ta odróżnia istotowo człowieka od zwierząt, można by tak oto powiedzieć: różnica pomiędzy istotą człowieka (tj. pomiędzy jego byciem repre- 
zentantem wszelkiego rozumnego podmiotu) a jego własną indywidualnością, gdy zostanie przezeń uprzytomniona, czyni dopiero człowieka świadomym jego własnej skończoności jako takiej.

Wspomniana wyżej różnica musi zostać przez człowieka uprzytomniona również dlatego, aby mógł on w ogóle uchwycić inną jeszcze różnicę. Idzie tu mianowicie o różnicę, jaka zachodzi między sposobem, w jaki jemu jako indywiduum zjawiają się rzeczy i ludzie, a tym sposobem, w jaki istnieją one zgodnie ze swą istotną naturą, i dlatego istnieją dla wszelkiego podmiotu rozumnego. Tylko też dlatego może człowiek, ,inne rzeczy lub istoty uczynić dla siebie przedmiotem zgodnie $\mathrm{z}$ ich istotną naturą"10, ponieważ posiada on zdolność rozróżniania pomiędzy sobą (jako indywiduum), a swoim zadaniem, zgodnie z którym ma być reprezentantem gatunku.

Na gruncie tych rozważań można by obecnie tak oto powiedzieć: Pojęcia gatunku oraz istoty oznaczają dla Feuerbacha określone idee. Regulatywny charakter tych idei warunkuje możliwość podejmowania przez człowieka prób poznania tego, czym rzeczy oraz osoby są zgodnie ze swoją istotą. Zdolność do podejmowania takich prób odróżnia decydująco człowieka od zwierząt. Można by to również wyrazić krócej: Pojęcia te oznaczają transcendentalny warunek wszelkiego kategorialnego poznania istoty przedmiotów. Jeżeli przeto Feuerbach używa tych pojęć w tym celu, aby na ich podstawie religię interpretować oraz krytykować, to dokonuje on tej interpretacji i krytyki z pozycji filozofii transcendentalnej. Będzie to niebawem jeszcze bliżej ukazane, iż ta interpretacja i krytyka religii, podjęta z punktu widzenia filozofii transcendentalnej, stanowiła dla Feuerbacha podstawę pozwalającą mu zrównać pojęcia gatunku $\mathrm{i}$ istoty $\mathrm{z}$ religijnym pojęciem Boga.

\section{Feuerbachowska transcendentalna interpretacja i krytyka religii. Wyzwanie dla teologii}

Dotychczasowe rozważania ukazały nam wyraziście, że centralne pojęcia Feuerbachowskiej filozofii religii, tzn. pojęcia gatunku oraz istoty, oznaczają „przedstawienie celu” (eine Zielvorstellung). Temu „przedstawieniu celu” człowiek (indywiduum) musi się poddać, aby — dzięki temu — stać się zdolnym do istotowego poznawania rzeczy i osób. Pojęcia te oznaczają zatem idee regulatywne w znaczeniu transcendentalnym. Takie zaś ujęcie natury owych pojęć rzuca zarazem określone światło na religijne pojęcie Boga. Albowiem również i to pojęcie oznacza warunek, od którego spełnienia zależy to, czy człowiek w ogóle potrafi dojść do rzeczywistego samopoznania. To właśnie dlatego religijny czlowiek wyznaje: „Bóg jest mi lepiej znany, niż ja sam dla

${ }^{10}$ Tamże, s. 40. 
siebie". Religijne pojęcie Boga oznacza zarazem warunek możliwości tego, aby człowiek potrafil poznawczo dotrzeć do rzeczy i ludzi. Tak więc człowiek religijny może też słusznie powiedzieć: „Bóg jest światłem, które oświeca każdego człowieka i każdą rzecz czyni widzialną". Jednakże wydaje się, iż na tej drodze nie uzyskało się jeszcze odpowiedzi na pytanie: Skąd czerpie Feuerbach pewność tego, że pojęcie Boga nie odróżnia się od pojęć gatunku oraz istoty jakimiś innymi, bardziej jeszcze zasadniczymi cechami?

Pierwsza odpowiedź na to pytanie rysuje się następująco: Własność bycia transcendentalnym warunkiem wszelkiego samopoznania, oraz wszelkiego poznania przedmiotowego, nie jest taką cechą pojęcia Boga, jaka w tym pojęciu występuje obok innych cech. Jest ona bowiem oznaką poznawczą tego, iż to najważniejsze pojęcie religijne rzeczywiście oznacza Boga, nie zaś coś innego. Boskość Boga wskazuje się podkreślając to, że On nigdy nie jest pewnym tylko przedmiotem poznania, występującym obok innych przedmiotów, lecz że bez Niego żaden w ogóle przedmiot nie mógłby zostać poznany: chociażby nawet był nim sam poznający siebie człowiek.

Jednakże druga możliwa odpowiedź brzmi następująco: Feuerbach był przeświadczony o tym, że nawet wszystko to, co religie i chrześcijaństwo ponadto jeszcze mówią o Bogu, pozwala się wywieść z transcendentalnego charakteru pojęcia Boga. W swej książce $O$ istocie chrześcijaństwa próbuje on następująco ująć i wyrazić to swoje przekonanie. Powiada on tam mianowicie, że wszelkie wypowiedzi wiary chrześcijańskiej (np. nauka o tym, że Syn pochodzi od Ojca jako Wiekuiste Słowo, że w Słowie tym świat został stworzony, że przez Jego cierpienia ludzie zostali zbawieni, itp.) należy interpretować jako słowa mówiące o warunku, który czyni człowieka w ogóle zdolnym do tego, aby on siebie samego oraz świat poznał i umiłował. Feuerbach stara się ów warunek dokładniej opisać. Stwierdza, że warunek ten polega na wymaganiu, aby się poddać ideom regulatywnym i w ten sposób stać się reprezentantem gatunku. W taki to sposób określał on — jak pamiętamy — istotę człowieka. Dlatego też - według mniemania Feuerbacha - wszelkie religijne poznanie oraz miłość Boga jest zawsze jedynie obrazowym sposobem wyrażenia tego, iż człowiek - z konieczności swej własnej istoty — czyni własny gatunek przedmiotem swego poznania i swojej miłości. W ten sposób on siebie samego jako indywiduum poddaje (podporządkowuje) temuż gatunkowi. Tak to człowiek jako istota rozumna - zyskuje samego siebie jako reprezentanta wszystkich rozumnych podmiotów.

Jak już wspomniano, Feuerbach pretendował do tego, aby przede wszystkim być komentatorem (tłumaczem) religii, nie zaś po prostu jej krytykiem. Dążąc do tego, aby uczynić zrozumiałymi wypowiedzi religijne, pragnie on zarazem ukazać ich prawdziwe znaczenie. Podjęcie tegoż roszczenia oznacza zarazem próbę wytrzymałości (Bewährungsprobe) dla rozwijanej przezeń filozofii. Ażeby sprostać tej próbie musi on wykazać, że jego wyjaśnienie rzeczywiś- 
cie uwidacznia ukryte jądro znaczeniowe wszelkich religijnych wypowiedzi. Tylko bowiem w tej mierze, w jakiej to mu się udaje, może on twierdzić o swej filozofii: „Jako stworzona $\mathrm{z}$ istoty religii zawiera ona [...] w sobie samej prawdziwą istotę religii, jest sama w sobie i dla siebie jako filozofia - religią"11. Obecnie można by tutaj dodać wyjaśniająco, iż Feuerbach może podjąć próbę wytrzymałości swej filozofii, tj. może pretendować do wyjaśnienia wszelkich religijnych wypowiedzi, dzięki dwojakiej podstawie. Pierwszą z nich stanowi fakt, iż przyjęte przezeń pojęcia gatunku oraz istoty opisują transcendentalne warunki możliwości wszelkiego kategorialnego poznania samego siebie oraz świata. Drugą zaś podstawą jest dla niego to, że pojęcie Boga - podobnie jak tamte dwa pojęcia - również jest zasadniczo odmienne od wszelkich pojęć odnoszących się do samych tylko wewnątrzświatowych przedmiotów, a to dzięki swemu transcendentalnemu znaczeniu.

To spotkanie pomiędzy myślą Feuerbacha a chrześcijańską teologią stanowi próbę wytrzymałości tak dla tej jego myśli, jak i dla chrześcijańskiej teologii. Zadaniem teologii staje się obecnie pokazanie tego, że Feuerbach nie tylko błędnie określił istotę religii, lecz że również warunki możliwości poznania ujął on w sposób nader niekompletny. Feuerbach doszedł do wniosku, że wszelka posiadana przez człowieka świadomość Boga jest tylko pewnym pośrednim sposobem realizowania się ludzkiej samoświadomości. Otóż wniosku tego można uniknąć tylko wówczas, gdy się podda krytyce poprzedzające go logicznie założenie. Założenie to polega na przekonaniu, iż dla wypełnienia przez człowieka właściwego mu transcendentalnego zadania (polegającego na tym, aby w teorii i praktyce tak się zachowywać, iżby rzeczy mogły mu się pokazywać „zgodnie z ich istotną naturą”), wymagane byłoby wyłącznie poddanie się człowieczego indywiduum pod regulatywne wymagania idei gatunku.

Argument umożliwiający krytykę owego założenia pozwala się wyprowadzić z rozważań starszych niż Feuerbachowe. Należy tutaj zwłaszcza wyjść od wskazówki Immanuela Kanta, odnoszącej się do dialektyki czystego rozumu. Idzie tu mianowicie o wskazywane przez Kanta zadania, które są równie niezbywalne jak niewykonalne. Uważał on je - jak wiadomo - za związane $\mathrm{z}$ dziedziną praktycznego posługiwania się czystym rozumem. Do zadań takich należy — przede wszystkim — to, aby człowiek, który sam siebie poznał jako grzesznika, o własnych siłach się poprawił i tak uczynił siebie człowiekiem, na którego Bóg spogląda $\mathrm{z}$ upodobaniem. Jednakże zrozumienie tego, w jaki to sposób złe drzewo mogłoby przynieść dobry owoc, przekracza zdaniem Kanta całkowicie nasze zdolności pojmowania. Do takich niezbywalnych, a przecież zarazem niewykonalnych, zadań należy również powinność, ażeby przez moralnie umotywowane a zarazem skuteczne postępowanie w tym świecie stworzyć warunki do tego, aby rzeczywiście zaistniał w tym świecie inny, tzn. prawdzi-

11 Tamże, s. 35. 
wie moralny porządek. Otóż zadanie to dlatego jest niewykonalne, ponieważ $\mathrm{w}$ istniejącym świecie siła potrzebna do przeprowadzenia zamierzonych celów zmniejsza się (a nie zwiększa) proporcjonalnie do czystości przekonań. Dlatego ten, kto chce skutecznie działać w celu zmiany tego świata, musi iść na rozmaite kompromisy, które sprzeciwiają się czystości jego przekonań. Natomiast ten, kto w pełni chce pozostać wiernym swoim przekonaniom, musi za to zapłacić nieefektywnością swych działań. Niezbywalność a jednocześnie niewykonalność tego rodzaju zadań posiada ten skutek, iż rozum, stawiając sobie za cel ich wypełnienie, zaplątuje się nieuchronnie w sprzeczności. Sprzeczności te rozwiązują się tylko w oparciu o tzw. postulaty (rozumu praktycznego), dzięki którym zadania te mogą zostać urzeczywistnione. Kant mówil tutaj o ufności wobec „łaskawych wyroków Boga”, która to ufność może grzesznika uczynić sprawiedliwym. Mówił również o ufności co do „Królestwa Bożego”, w którym nie będzie już istniała żadna sprzeczność pomiędzy prawem moralnym a prawem natury. Tam dopiero będzie więc możliwe równoczesne zachowanie czystości przekonań oraz skuteczności działania.

Obecnie należy jeszcze postawić następujące pytania: Czy istnieje podobna dialektyka rozumu, gdy idzie o jego użycie teoretyczne? Czy teoretyczne używanie rozumu, które czyni możliwym wszelkie obiektywne poznanie, zawiera w sobie zarazem takie jego praktyczne używanie, którego dialektyka musi być rozwiązywana poprzez postulat religijnej nadziei? Otóż dopiero wtedy, gdyby to zostało wykazane, można by zasadnie utrzymywać, że pojęcie Boga posiada charakter transcendentalny, tzn. że oznacza ono warunek możliwości wszelkiego samopoznania oraz wszelkiego poznania przedmiotowego. Zarazem uniknęłoby się Feuerbachowskiego wniosku, że pojęcie Boga naprawdę oznacza jedynie istotę człowieka (tzn. jego istotę jako rozumnego podmiotu, który podporządkowuje sam siebie pod idee regulatywne i w ten sposób zachowuje się jako czysty reprezentant gatunku).

\section{Skryta dialektyka Feuerbachowskich pojęć istoty i gatunku}

Teoretyczne posługiwanie się rozumem, które umożliwia nam poznawcze ujmowanie rzeczy i osób zgodnie $\mathrm{z}$ ich istotną naturą, rzeczywiście zawiera w sobie pewien moment praktyczny. Znajduje się on w moralnej decyzji indywiduum dotyczącej tego, aby poddać się pod nakazy rozumu. Rozum żąda od niego, aby on swoje indywidualne poglądy i zamiary uznał za niemiarodajne (für unmassgeblich zu erklären) i aby to jedynie uznawał za ważne w sposób obiektywny, co myśli i czego pragnie funkcjonując jako uniwersalnie wymienialny podmiot rozumny. Otóż związana z tym decyzja jest praktycznym założeniem wszelkiego teoretycznego poznawania, do jakiego człowiek jest zdolny. 
Feuerbach mówi tutaj o „tryumfie” rozumu nad indywiduum. „Czyż zapał do wiedzy nie jest najpiękniejszym tryumfem, jaki święci rozum nad Tobą?"12 W tym poddaniu się indywiduum pod rozum idzie o to, aby zostało ono spełnione lekko i radośnie. W tym właśnie dostrzega Feuerbach analogię, jaka zachodzi pomiędzy zapałem naukowym a religijnym uwielbieniem Boga. Albowiem w religii również ma miejsce poddanie się człowieka Woli Boga w sposób lekki i radosny. Człowiek religijny — powiada — może z radością zawołać: „Zabierz, o Panie, całą moją wolność!” Feuerbach uważa, iż ma w pogotowiu łatwe wyjaśnienie powodu tej radości religijnego człowieka. Wszak można by o nim — dodaje — powiedzieć: „Dla samego siebie człowiek może być niczym, gdyż wszystko, co sobie odbiera, w Bogu nie ginie, lecz zachowuje się"13. To zaufanie religijnego człowieka do Boga, ożywione przekonaniem, iż on sam siebie odnajdzie w swoim oddaniu się Bogu, pozwala się obecnie następująco wyjaśnić. Idzie mianowicie o to, że człowiek religijny posiada pełne prawo do pewności, iż siebie rzeczywiście nie zatraci w takim samoofiarowaniu. Jednakże —zdaniem Feuerbacha - podstawa tej pewności jest przez religijnego człowieka niewłaściwie pojmowana. Wbrew bowiem jego własnym mniemaniom człowiek ten nie ofiarował siebie tej obcej względem niego rzeczywistości, jaką byłby Bóg, lecz ofiarował on siebie swej własnej istocie, tj. temu, czym on już zawsze jest jako rozumny podmiot.

To rzekome ofiarowanie się człowieka obcej mu (radykalnie) rzeczywistości Boga, jeśli zostanie należycie zrozumiane, pozwala się zatem pojąć jako ofiarowanie się ludzkiego indywiduum dla jego własnej istoty. Analogiczny sens samoofiarowania się ludzkiego indywiduum uwidacznia się bezpośrednio i wyraziście w przeżyciu naukowego zapału. Natomiast w przeżyciu religijnego uniesienia ów stan rzeczy zostaje doświadczony przezeń w taki sposób, iż prowadzi to do (zasadniczych) nieporozumień. To mianowicie, co w naukowym zapale manifestuje się bez obrazu i dlatego w sposób wolny od nieporozumień, w przeżyciu religijnym zostaje oznaczone pod obrazem ofiary dla Boga. Tak więc-zdaniem Feuerbacha - wewnętrzna sprzeczność religijnej świadomości, która tam oczekuje swego samoodnalezienia, gdzie „człowiek musi być niczym, aby Bóg stał się wszystkim", rozwiązuje się poprzez przyjęcie tego, iż gorliwość religijnego samoofiarowania się jest tylko wyrazem niezrozumienia prawdziwej natury naukowego zapału. Albowiem to właśnie w naukowym zapale ludzkie indywiduum oddaje się swojej własnej istocie jako rozumnemu podmiotowi.

Powyższej interpretacji można by jednak postawić następujący zarzut. Idzie mianowicie o to, że stosunek indywiduum do gatunku - jako do wspólnoty wszystkich podmiotów rozumnych — okazuje się być ostro antagonistycz-

12 Tamże, s. 43.

13 Tamże, s. 76. 
ny, gdy zostanie przez nas ujęty jako sam dla siebie. Dlatego stosunek ten nie daje żadnej podstawy dla jakiejkolwiek nadziei oraz pojednania. Subiektywne potrzeby i skłonności ludzkiego indywiduum muszą zamilknąć tam, gdzie powinien przemawiać rozum. A zatem to, co Feuerbach twierdzi o stosunku religijnego człowieka do Boga, posiada rzeczywiste zastosowanie tam, gdzie idzie o stosunek indywiduum do rozumu. Ażeby bowiem rozum mógł stać się wszystkim, indywiduum musi stać się niczym. Dlatego Feuerbach całkiem słusznie mówi o „tryumfie" rozumu nad indywiduum. Jednakże nadzieja na pojednanie, które mogłoby nastąpić po owym tryumfie, nie jest czymś immanentnym dla etosu nauki. Natomiast ufność w owo pojednanie należy rzeczywiście do etosu religii. Jest rzeczą pewną, iż religia żąda od swoich zwolenników gotowości do ofiarowania się Bogu aż po ofiarę ze swego życia (aż do wylania krwi). Jednakże tutaj, w przeciwieństwie do etosu nauki, można łatwo uzasadnić, dlaczego wymaganie gotowości do takiej ofiary powiązane jest $\mathrm{z}$ obietnicą pojednania i ocalenia. Wszak człowiek, który się religijnie ofiarował swojemu Bogu, uzyskuje dzięki temu wspólnotę z Boskim samoofiarowaniem się „,za wielu". Tego rodzaju pewność nie przynależy bynajmniej do samej tylko wiary chrześcijańskiej, jest ona bowiem cechą posłannictwa wielu innych religii, również tzw. religii „archaicznych”. Pozostając we wspólnocie z Bogiem, Który ofiarował siebie „za wielu”, człowiek religijny również wydaje wtedy siebie „za wielu” — a zatem „za gatunek” (ludzki). Jednakże doświadcza on wówczas zarazem, iż Bóg ofiarował siebie nie tylko za ludzkość, lecz i za każdego poszczególnego człowieka, a zatem i za niego samego. Wyznanie wiary w to, iż Bóg (lub mówiąc po chrześcijańsku: Syn Boży) umarł „za wielu”, nie wyklucza bynajmniej ufności, że umarł On również za mnie — za mnie wziętego w mojej konkretnej indywidualności. Jeśli bowiem człowiek naśladuje (i tak współspełnia) Boskie samoofiarowanie się „za wielu”, może najsłuszniej ufać, że również on sam, jako to oto konkretne indywiduum, uzyska przebaczenie i zostanie uratowany (tj. zbawiony).

Dlatego też nie jest bynajmniej tak, jak uważał Feuerbach, jakoby „tryumf rozumu” był modelem, który został „projektowany na niebo” (das „an den Himmel projiziert wurde") i w ten sposób wytworzył religijną nadzieję. Raczej należy przyjąć wprost odwrotnie, że pierwotnym modelem jest nadzieja religijna, ukazująca to, iż człowiek, jeśli znajdzie poprzez oddanie się dla ludzkości wspólnotę z Bogiem, dzięki temu zostanie uratowany właśnie jako indywiduum. Ten pierwotny model religijnej nadziei wytworzył w zeświecczonej postaci nadzieję podmiotu rozumnego. Ta zeświecczona nadzieja obiecuje mu, iż po wzniesieniu się do surowej bezinteresowności „reprezentanta gatunku” (rodzaju ludzkiego), zdobędzie przez to jako indywiduum swoją godność oraz usprawiedliwienie swej egzystencji. Feuerbach sądzil, że przez swoją teorię o „tryumfie rozumu nad indywiduum” rozwiąże sprzeczność, jaka (rzekomo) zachodzi w religijnej świadomości. O wiele słuszniej jednak można powiedzieć 
przeciwnie: Opisywany przez Feuerbacha zapał naukowy jest jedynie zeświecczonym odbiciem religijnego uniesienia. Uniesienie to wiąże się z przeżywaniem wspólnoty z Bogiem, Który oddał się „,za wielu” i równocześnie za każdego człowieka z osobna. Dlatego uniesienie to przeniknięte jest żądaniem bezinteresowności oraz nadzieją na własne zbawienie indywiduum.

Jakie to wszystko posiada znaczenie dla Feuerbachowskiej interpretacji i krytyki religii, dokonywanej z punktu widzenia filozofii transcendentalnej? Otóż wcześniej zostało już powiedziane, iż ten warunek transcendentalny, który czyni możliwym wszelkie samopoznanie a wraz $\mathrm{z}$ nim wszelkie poznanie przedmiotowe, staje się skuteczny przede wszystkim przez to, że pozwala ludzkiemu indywiduum poznać jego zasadnicze zadanie. Idzie tutaj konkretnie o to zadanie, aby postępować jako uniwersalnie zastępowalny reprezentant wszelkiego rozumnego podmiotu. Stwierdzenie to jest zgodne z tradycyjnym rozumieniem sprawy. Transcendentalny warunek wszelkiego odnoszenia się rozumu do jego przedmiotu znajduje się w ideach regulatywnych, tzn. w przedstawieniach celu, związanych z wypełnianiem określonych zadań, które rozum sam sobie musi postawić, ażeby on mógł stać się zdolnym do poznawania przedmiotów. W świadomości tego rodzaju zadań znajduje się moment praktyczny, który jest implikowany przez każde teoretyczne używanie rozumu. Do tych spostrzeżeń dołącza się tu jeszcze następujące pytanie: Czy świadomość niezbywalności pewnego zadania gwarantowałaby już tym samym jego wypełnialność?

Na pytanie to należałoby następująco odpowiedzieć. Otóż sama tylko świadomość niezbywalności pewnego zadania (np. zadania, aby zachowywać się w myśleniu i chceniu tylko jako reprezentant gatunku) nie daje żadnych podstaw do pewności, że zadanie to może zostać wypełnione. Albowiem świadomość niezbywalności owego zadania zawiera w sobie sprzeczność. Z jednej bowiem strony indywiduum, znajdując się w sytuacji wyboru moralnego, samo musi się zdecydować. Tej decyzji nikt nie może mu odjąć, jest więc ono w niej niezastępowalne. $\mathrm{Z}$ drugiej jednak strony, ma się ono właśnie w ten sposób zdecydować na to, aby być uniwersalnie zastępowalnym reprezentantem wszelkiego rozumnego podmiotu. Powyższa sprzeczność musi zostać rozwiązana, jeśli ma być możliwa ukształtowana moralnie decyzja, i jeśli ma być wraz z nią możliwe teoretyczne używanie rozumu. Jednakże nie inaczej może ona zostać rozwiązana, jak tylko poprzez pełne nadziei zaufanie. Lecz owo zaufanie nie może być skierowane ku gatunkowi, bądź ku anonimowemu rozumowi ludzkiemu. Idzie tutaj natomiast o pełne nadziei zaufanie, że indywiduum, w swojej bezinteresownej ofierze dla gatunku (mówiąc zaś religijnie: „dla wielu") napotka Boga, który na mocy swego samoofiarowania się za każdego poszczególnego człowieka jest w stanie uratować godność oraz prawo egzystencji (das Existenzrecht) indywiduum. 
Można by to wyrazić krócej: Nie „tryumf rozumu”, który doświadczamy w postaci naukowego zapału, lecz tylko spotkanie z Bogiem — który się ofiarowuje ,za wielu”, a zarazem za każdego poszczególnego człowieka — uchyla tę sprzeczność, która w przeciwnym razie grozi załamaniem się każdego teoretycznego używania rozumu.

Feuerbach słusznie podkreśla, że gatunek (rodzaj ludzki) jest koniecznym przedmiotem wszelkiego ludzkiego poznania oraz miłości. Jednakże tylko dlatego uzyskuje on to znaczenie, ponieważ uprzedzająca miłość Boga jest warunkiem, który chroni człowiecze samoofiarowanie się ,za wielu” od stania się samobójstwem. Wraz z tym owa uprzedzająca miłość Boża chroni ludzkie indywiduum przed zniszczeniem jego własnej godności. Tak oto sprzeczność, zachodząca zarówno w praktycznym jak i teoretycznym używaniu rozumu, rozwiązuje się tylko dzięki przyjęciu tego, iż człowiek podporządkowuje się żądaniu stania się bezinteresownym reprezentantem gatunku w tym celu, aby dzięki temu napotkać Boga i zjednoczyć się z Jego samoofiarowaniem się. Przyjęcie czegoś takiego jest - mówiąc po kantowsku — koniecznym postulatem. Postulat ten chroni rozum przed tym, aby on, w swoim „tryumfie” nad ludzkim indywiduum, nie zatracił człowieka wraz z jego godnością.

Ttumaczył ks. R. Rożḋ̇eński 